\title{
Bevacizumab rechallenge kezelés hatékonysága vastagbéldaganat májáttétje esetén
}

\author{
Deme Dániel dr. ${ }^{1}$. Telekes András dr. ${ }^{1,2}$ \\ 'Szent Lázár Megyei Kórház, Onkológiai Osztály, Salgótarján \\ ${ }^{2}$ Semmelweis Egyetem, Általános Orvostudományi Kar, Geriátriai Tanszéki Csoport, Budapest
}

\begin{abstract}
Mivel a vastagbéldaganatok terápiás lehetőségei limitáltak, az egyes kezelések újraindítása (rechallenge) a terápiás stratégia részévé vált. Ezt példázza esetünk is. 65 éves nőbetegnél sürgősséggel resectio történt sztenotizáló sigmadaganat miatt. Sebészileg inkurábilis multiplex májáttétek igazolódtak. Szövettan: adenocarcinoma (grade II, pT3pNlcMl). 13 ciklus bevacizumab (BEV) + FOLFOX, majd 2 ciklus BEV + kapecitabin és 11 ciklus BEV + 5FU/ LV kezelést kapott. 2. vonalbeli terápiaként 28 ciklus cetuximab (CET) + FOLFIRI kezelésben részesült. A 3. vonalban - tekintettel a májra lokalizálódó betegségre és a páciens preferenciája alapján - két ciklus transarterialis chemoembolisatiót kapott (doxorubicin + lipiodol). A 4 . vonalban 4 ciklus trifluridin/tipiracil kezelést kapott. Az 5. vonalban 13 ciklus BEV + FOLFIRI (rechallenge) kezelésben részesült, mely 6,5 hónappal hosszabbította meg az élettartamát.
\end{abstract}

Orv Hetil. 2018; 159(31): 1284-1290.

Kulcsszavak: vastagbélrák, kemoterápia, bevacizumab, rechallenge

\section{Effectivity of bevacizumab rechallenge treatment in liver metastasis of colon cancer}

Since the therapeutic options for colon cancer are limited, the reinduction of treatments (rechallenge) is part of the therapeutic strategy. Our case is an example for that. A 65-year-old female patient was operated on stenotizing sigmoid cancer. Resectio was performed. Surgically incurable multiple hepatic metastases were proven. The histology revealed adenocarcinoma (grade II, pT3pNlcMl). In the first line, 13 cycles of bevacizumab $(\mathrm{BEV})+$ FOLFOX followed by 2 cycles of BEV + capecitabine and 11 cycles of $\mathrm{BEV}+5 \mathrm{FU} / \mathrm{LV}$ were administered. In the second line, 28 cycles of cetuximab (CET) + FOLFIRI were given. In the third line, due to liver limited disease and based on the preference of the patient, two cycles of transarterial chemoembolisation (doxorubicin + lipiodol) were administered. In the fourth line, four cycles of trifluridine/tipiracil were given. In the fifth line, 13 cycles of BEV + FOLFIRI were given, as a rechallenge, which improved the overall survival by 6,5 months.

Keywords: colon cancer, chemotherapy, bevacizumab, rechallenge

Deme D, Telekes A. [Effectivity of bevacizumab rechallenge treatment in liver metastasis of colon cancer]. Orv Hetil. 2018; 159(31): 1284-1290.

(Beérkezett: 2018. március 23.; elfogadva: 2018. április 21.)

\section{Rövidítések}

$5 \mathrm{FU}=5$-fluorouracil; $\mathrm{BEV}=$ bevacizumab; $\mathrm{BRAF}=\mathrm{a} \mathrm{B}-\mathrm{Raf}$ protoonkogént kódoló gén; $\mathrm{BRCAl} / 2=$ breast cancer $1 / 2$ gén; CAPE = kapecitabin; CAPOX = kapecitabin + oxaliplatin; $\mathrm{CD}=$ (cluster of differentiation) differenciációs klaszter; CET = cetuximab; $\mathrm{CI}=$ konfidenciaintervallum; $\mathrm{CIN}=$ kromoszó- mainstabilitás; CMS = (consensus molecular subtypes) konszenzusmolekuláris altípusok; $\mathrm{CpG}=$ foszfodiészterkötéssel kapcsolt citozin és guanin; $\mathrm{CRC}=($ colorectal cancer $)$ vastagés végbélrák; CSS = (cancer-specific survival) daganatspecifikus túlélés; CTC = (circulating tumor cell) keringő daganatsejt; $\mathrm{DCR}=($ disease control rate $)$ betegség-kontrollráta; DFS = 
(disease-free survival) betegségmentes túlélés; DNS = dezoxiribonukleinsav; EGFR = az epidermális növekedési faktor receptora; $\mathrm{EMK}=$ egyedi méltányossági kérelem; ERCP = endoszkópos retrográd cholangiopancreatographia; ESMO = (European Society of Medical Oncology) Európai Onkológiai Társaság; FOLFIRI = 5-fluorouracil + leukovorin (kalcium-folinát) + irinotekán; FOLFOX $=5$-fluorouracil + leukovorin (kalcium-folinát $)+$ oxaliplatin; $\mathrm{GC}=$ (gastric cancer $)$ gyomorrák; $\mathrm{Gln}=$ glutamin; $\mathrm{HR}=$ (hazard ratio) kockázati hányados; Ile = izoleucin; K-ras = Kirsten rat sarcoma; KRAS = K-ras fehérjét kódoló gén; $\mathrm{LV}=$ leukovorin (kalcium-folinát); $\mathrm{MMR}=$ (mismatch repair) DNS-javító mechanizmus; mRNS $=$ (messenger RNA) hírvivő ribonukleinsav; MSI = mikroszatellitainstabilitás; MSS = mikroszatellitastabil $;$ NEAK = Nemzeti Egész ségbiztosítási Alapkezelő; OEP = Országos Egészségbiztosítási Pénztár; OIIS = (oxaliplatin immune-induced syndrome $)$ oxaliplatin immunindukált szindróma; OS = (overall survival $)$ teljes túlélés; PFS = (progression-free survival) progressziómentes túlélés; RAS = (rat sarcoma) patkánysarcoma; RFS = (recurrence-free survival) kiújulásmentes túlélés; RNS = ribonukleinsav; $\mathrm{RR}=$ (relative risk) relatív kockázat; $\mathrm{SRBC}=$ serum deprivation response-related gene product that binds to $c$-kinase; TACE $=$ transarterialis chemoembolisatio; $\mathrm{TNM}=$ tumor nodus metas tasis; TOP2A = topoizomeráz-2-alfa; TOPO = topoizomeráz; TS $=$ timidilát-szintáz; Val $=$ valin

Az Európai Onkológiai Társaság (European Society of Medical Oncology - ESMO) vastag- és végbéldaganatok (CRC) kezelésére vonatkozó, 2016-ban megjelent konszenzusirányelve az áttétes betegség utolsó kezelési szekvenciájában ajánlja, hogy az első vonalban hatékonynak bizonyult kombinációs sémát ismét megkaphassa a páciens (rechallenge) [1].

A rechallenge során olyan kezelést kap a páciens, amely mellett progresszív betegség alakult ki korábban, tehát a daganatos góc növekedéséért felelős klónok az adott szer(ek)re rezisztenssé váltak. A rechallenge kezelés hatásosságának hátterében az az elmélet áll, hogy a rezisztenssé vált daganatsejtek ismét visszanyerhetik érzékenységüket a korábbi kezeléssel szemben. A rechallenge

1. táblázat A páciensek stratifikációja az első vonalbeli kezelés megválasztására nézve (ESMO 2012)

\begin{tabular}{lll}
\hline Csoport & Megnevezés & Jellemző \\
\hline 0. & $\begin{array}{l}\text { Máj- vagy tüdőáttét, } \\
\text { reszekálható R0-ra }\end{array}$ & $\begin{array}{l}\text { Kezelés nélkül is reszekálha- } \\
\text { tó áttét }\end{array}$ \\
1. & $\begin{array}{l}\text { Máj- vagy tüdőáttét, nem } \\
\text { reszekálható R0/1-re }\end{array}$ & $\begin{array}{l}\text { Indukciós kezelés után } \\
\text { reszekálható áttét }\end{array}$ \\
2. & Intermedier intenzív kezelés & $\begin{array}{l}\text { Palliatív célú kezelés (ritkán } \\
\text { reszekálható) }\end{array}$ \\
3. & $\begin{array}{l}\text { Nem intenzív/szekvenciális } \\
\text { kezelés }\end{array}$ & $\begin{array}{l}\text { Daganatos progresszió } \\
\text { megelózése (minimális } \\
\text { mellékhatásokkal járó } \\
\text { kezelés alkalmazása) }\end{array}$ \\
& &
\end{tabular}

ESMO = Európai Onkológiai Társaság; R0 = patológiailag daganatmentes sebszél; Rl = makroszkóposan daganatmentes, de patológiailag pozitív sebszél megkülönböztetendő a reindukciótól, mely utóbbi esetben a korábban alkalmazott kezelés leállítása nem progresszió (például adjuváns kezelés vagy tervezett terápiás szünet) miatt történt, tehát a daganatsejtek terápiás érzékenysége megmaradt [2].

A rechallenge kezelésról viszonylag kevés adat áll rendelkezésre. Az oxaliplatin újraindításáról eltérőek a vélemények. Egyesek egyáltalán nem javasolják ennek alkalmazását [3], míg mások a rechallenge kezelés alkalmazhatóságát a hiperszenzitivitás mértékétől és az egyéb klinikai faktoroktól teszik függővé [4]. Így a CRC ellátására új terápiás stratégia, a folyamatos kezelés modellje van kialakulóban [5]. Ez a modell az individualizált kezelési stratégiát helyezi a középpontba, amely a fenntartó kezeléseket, agresszív protokollokat, a rechallenge-et a korábbi kezeléssel (amelyre a beteg akkor reagált), illetve a korábban már alkalmazott kezelések új módon történő kombinációját egyaránt magában foglalja $[6,7]$.

\section{Esetismertetés}

65 éves nőbetegnél fáradékonyság, étvágytalanság, szél-, székletmegállás és hasi fájdalmak miatt történt sürgősségi mưtét során sztenotizáló sigmadaganat és sebészileg inkurábilis multiplex májáttétek igazolódtak. Resectio segmentalis sigmae történt. A szövettan adenocarcinoma (grade II, pT3pNlcMl) fennállását mutatta. Mivel a kiterjesztett rat sarcoma (RAS-) vizsgálatra 1 hónapot várni kellett, az ESMO 2012-es konszenzusirányelve [8] alapján Group 2 szerinti intermedier intenzív terápiát ( 1 . táblázat) kezdtünk bevacizumab $(\mathrm{BEV})+$ oxaliplatin + 5-fluorouracil $(5 \mathrm{FU})+$ leukovorin $(\mathrm{LV})$, úgynevezett BEV + FOLFOX séma szerint, melyből tizenhárom kezelést adtunk, majd fenntartó kezelést folytattunk a mellékhatásoktól (phlebitis vagy kéz-láb szindróma) függően $5 \mathrm{FU} / \mathrm{LV}$ vagy kapecitabin (CAPE) kemoterápiás gerinccel (összesen két ciklus BEV + CAPE és hét ciklus $\mathrm{BEV}+5 \mathrm{FU} / \mathrm{LV})$.

A stabil betegségre való tekintettel az egy éven túli kezelés folytatásához az Országos Egészségbiztosítási Pénztár (OEP) Ártámogatási Főosztályától egy hónapon belül megkaptuk az egyedi méltányossági kérelemre (EMK) az engedélyt, így még öt ciklus BEV + 5FU/LV tudtunk megadni. A májáttétek progressziója miatt a kiterjesztett RAS vad típusra tekintettel 2 . vonalbeli terápiaként cetuximab $(\mathrm{CET})+$ irinotekán $+5 \mathrm{FU} / \mathrm{LV}$, úgynevezett CET + FOLFIRI kezelést indítottunk. Huszonnyolc ciklus CET + FOLFIRI kezelés után észlelt progresszió miatt - tekintettel a májra lokalizálódó betegségre és a páciens preferenciája alapján - a beteg két ciklus transarterialis chemoembolisatiót (TACE) kapott (doxorubicin + lipiodol). Novum májlaesio miatt két ciklus trifluridin/tipiracil kezelést kapott, majd a jó válasz miatt benyújtott EMK alapján az OEP újabb két ciklust engedélyezett. A májáttétek progressziója miatt a Nemzeti Egészségbiztosítási Alapkezelő (NEAK) Ártá- 
mogatási Főosztályához benyújtott EMK alapján az engedélyre történő egy hónapos várakozási idő után BEV rechallenge kezelést kezdtünk FOLFIRI gerincterápiával. Az egy hónap alatt icterus alakult ki, mely a kezelés indítását követően megszűnt. A páciensnél kéthavonta végeztettünk CT-vizsgálatokat, melyek stabil betegséget mutattak. A tizenharmadik kezelés alkalmával a betegnek gyomortáji panaszai jelentkeztek, és vérnyomása kiugrott (200 Hgmm-es szisztolés érték). Protonpumpagátlót alkalmaztunk, és a terápiát kiegészítettük kalciumcsatorna-blokkoló adásával. A rapidan kialakuló icterus miatt készült ultrahangvizsgálat nem mutatott sem intra-, sem extrahepaticus epeúttágulatot, azonban epehólyag-megvastagodást és epekövességet írt le. Az anemizálódás miatt vörösvértest-transzfúzióban részesítettük. A májenzimek csak mérsékelt emelkedést mutattak. Az endoszkópos retrográd cholangiopancreatographia (ERCP) során proximális epeúti elzáródás ábrázolódott, és plastic stent implantációjára került sor. Periproceduralisan 3. generációs cefalosporint (cetriaxon) alkalmaztunk. A beavatkozás utáni napon sárgasága javult, ám a következő napon ismét mélyült, ami a stent kicsúszására utalt. Percutan transhepaticus drén beültetését terveztük, azonban a páciensnél ismét vérnyomáskiugrás jelentkezett, majd a végbélből származó jelentős mennyiségü vérzés. A hypovolaemiás sokk miatt folyadékresuscitatióban és vörösvértest-transzfúzióban részesítettük, melyekre állapota stabilizálódott. Per rectum kóros nem volt tapintható. Kolonoszkópos vizsgálatot terveztünk, azonban vérzése ismételten jelentkezett, mely miatt folyadékresuscitatióra és ismételt transzfúzióra volt szükség. Az alkalmazott kezelés ellenére romló általános állapot miatt a további vizsgálatoktól eltekintettünk. Így páciensünk a 70. életévében, az áttétes vastagbélrák miatt alkalmazott 51,32 hónap kezelést követően keringési elégtelenség tünetei között elhunyt.

Jóllehet a sectio során a halál alapjául szolgáló állapotként hepatorenalis szindróma lett megjelölve, azonban a klinikai képet az obstrukciós sárgaság mellett a heveny gastrointestinalis vérzés uralta, melynek forrása a kialakult nyelőcső-varicositas volt. A jó rezervkapacitást (megtartott májfunkciós értékeket) mutató máj fokozatos metastaticus átépülése miatt a zsigeri artériás keringésben vasodilatatio, míg renalisan vasoconstrictio lépett fel, és ezen folyamattal párhuzamosan nyelöcső-varicositas is kialakult. A vérzés intenzitása a vérnyomás függvénye volt. A vérnyomás emelkedése (szimpatikus hatás és folyadékresuscitatio) fokozta a vérzést. A krónikus vérvesztéshez hozzájárultak a gyomorban és a nyombélben igazolódott fekélyek is. A vérzés következtében kialakult hypovolaemia magyarázta a sokkállapotot. A májkapuban lévő megnagyobbodott nyirokcsomók okozták az epeúti elzáródást. Az epehólyagban a kövesség talaján gennyes gyulladás alakult ki, mely felszálló cholangitis kialakulását okozta. Az ERCP során beültetett stent kicsúszott, és a vékonybélben volt fellelhető, mely szövődményt nem okozott. A szerzők véleménye alapján a ke- ringési elégtelenségnek kettős oka volt tehát, egyrészt a varixvérzés okozta hypovolaemiás, másrészt a gennyes epehólyag-gyulladás miatti szeptikus sokk.

\section{Megbeszélés}

A CRC heterogenitást mutat a betegség biológiai viselkedésében, a terápiás válaszban és a prognózisban. Ennélfogva a patológiai leletben kötelező rögzíteni a 'tumor nodus metastatis' (TNM-) stádiumot, a reszekciós szél méretét, a daganatnövekedés jeleit (az invazív határon daganatsejtek vagy maximum 5 daganatsejtból álló csoportok jelenléte), a mikroszatellitastátuszt, a gradust, a nyirokér-invázió meglétét, az érinvázió tényét és a perineuralis terjedés fennállását, mi több, a nyirokcsomókból és a távoli metastasisból is szövettani lelet volna szükséges a terápia optimalizálásához. A heterogenitásra itt csak egy példát említünk. Egy vizsgálatban $(\mathrm{N}=55)$ a K-ras, BRAF, PI3K géneket vizsgálták, a primer CRCben a tumor centrumában és az inváziós szélen. Tumorheterogenitást találtak a K-ras, BRAF, PI3K gének vonatkozásában 8,1 és 5 százalékban a primer daganaton belül. Ugyanez a primer daganat és a nyirokcsomó vonatkozásában az esetek 31, 4 és 13 százalékában; a primer daganat és távoli metastasis vonatkozásában 10, 5 és 0 százalékban fordult elő [9]. A kiterjesztett RAS-vizsgálat és a B-Raf protoonkogént kódoló gén (BRAF) mutációs statusának meghatározása prediktív jelentőségú az antiepidermális növekedési faktor receptor (EGFR-) terápiára vonatkozólag. Jelenleg a CRC-nek négy különböző molekuláris altípusát (konszenzusmolekuláris altípusokat [CMS]) ismerjük, melyeknek mind prognosztikus és prediktív jelentőségük van (2. táblázat). A CRC különféle típusaiban fellelhető gyulladásos infiltrátum vizsgálata jelentős különbségeket fedett fel a gyulladásos sejtek mennyiségében és elhelyezkedésében. Mindezen paraméterek segítséget nyújtanak abban, hogy

\begin{tabular}{l|l} 
2. táblázat & $\begin{array}{l}\text { A CRC négy molekuláris altípusa a konszenzusmolekuláris altí- } \\
\text { pusok szerint }\end{array}$
\end{tabular}

\begin{tabular}{ll}
\hline $\begin{array}{l}\text { A konszenzusmolekuláris } \\
\text { altípusok }\end{array}$ & Jellemzői \\
\hline CMS1 & $\begin{array}{l}\text { MSI-daganatok, CD8 citotoxikus } \\
\text { sejtinfiltráció, magas mutációs frekvencia }\end{array}$ \\
CIN-t hordozó daganatok, epithelialis- \\
marker-expresszióval és Wnt-útvonal- \\
aktivációval
\end{tabular}

$\mathrm{CD}=$ differenciációs klaszter; CIN = kromoszómainstabilitás; CMS = konszenzusmolekuláris altípusok; $\mathrm{CRC}=$ vastag- és végbélrák; KRAS = K-ras fehérjét kódoló gén; MSI = mikroszatellitainstabilitás; MSS = mikroszatellitastabil 
3. táblázat $\mid$ A daganatok heterogenitás szerinti felosztása

\begin{tabular}{|c|c|c|}
\hline Intertumoralis & \multicolumn{2}{|l|}{ Intratumoralis } \\
\hline \multirow[b]{2}{*}{$\begin{array}{l}\text { - Különböző } \\
\text { páciensek azonos } \\
\text { szövettani típusú } \\
\text { daganatai közötti } \\
\text { különbségek } \\
\text { - Egy páciens } \\
\text { szinkrón CRC-iben } \\
\text { rejlö különbségek }\end{array}$} & Térbeli & Időbeli \\
\hline & $\begin{array}{l}\text { A daganatban } \\
\text { megfigyelhető } \\
\text { különbségek }\end{array}$ & $\begin{array}{l}\text { Az egyén daganatai- } \\
\text { ban idővel kialakuló } \\
\text { genetikai változások }\end{array}$ \\
\hline
\end{tabular}

CRC = vastag- és végbélrák

a pácienseket különböző terápiás és prognosztikai csoportokba sorolhassuk. A CRC a heterogenitás szerint intertumoralis és intratumoralis csoportba sorolható (3. táblázat). Az intertumoralis heterogenitás magában foglalja a különböző pácienseknél diagnosztizált azonos szövettani típusú CRC-k közötti különbségeket, és ritkán az egy páciens esetén diagnosztizált szinkrón CRCben lévő különbségeket is. Az intratumoralis heterogenitás felosztható térbeli és időbeli heterogenitásra. A térbeli heterogenitás az egyes, daganatban megfigyelhetô különbségekre utal, így a primer daganat különböző genetikai alcsoportjaira vagy a primer és a metastaticus góc közötti eltérésekre. Az időbeli heterogenitás a CRC dinamikus természetére utal, vagyis az egyén daganataiban idővel kialakuló genetikai eltérésekre. A daganatokban gyakran megfigyelhető az intratumoralis heterogenitás, vagyis az egy daganatban jelen lévő számos daganatos szubpopuláció eltérő morfológiát, gyulladásos infiltrátumot, mutációs statust vagy génexpressziós profilt mutat [10].

A CRC heterogenitásával magyarázható, hogy az alkalmazott kezelésre érzékeny daganatsejtek osztódása gátlódik, vagy a sejtek apoptózis következtében elpusztulnak, míg a kezelésre nem érzékeny daganatsejtek túlélnek. Ezen utóbbi esetben a daganatsejtek vagy már eleve rezisztensek a terápiára, vagy pedig szerzett rezisztenciamechanizmus(ok) során válnak ellenállóvá a kezeléssel szemben. Ismert például, hogy az excision repair cross-complementing group I (ERCCl) expressziója oxaliplatinrezisztenciát jelez elöre. 22 vizsgálat metaanalízise alapján gyomorrákban $(\mathrm{GC})(\mathrm{n}=1242)$ és CRCben $(\mathrm{n}=1772)$ az oxaliplatinkezelésre adott terápiás választ szignifikánsan nem befolyásolta $(\mathrm{p}=0,337)$ az ERCCl polimorfizmusa (rs11615 - citozin/timin). GC-ban jelentősen rosszabb volt a terápiás válasz $(\mathrm{p}<0,05)$, azonban a polimorfizmus fennállása esetén mind a progressziómentes (PFS), mind a teljes túlélés (OS) jelentősen rövidebb volt a két daganattípust magában foglaló összesített elemzés szerint [PFS: kockázati hányados $(\mathrm{HR})=1,22 ; \mathrm{p}<0,001 ; 95 \%$-os konfidenciaintervallum (CI) 0,93-1,51 és OS: $\mathrm{HR}=1,12 ; \mathrm{p}<0,001$; 95\%-os CI 0,85-1,40] [11]. Egy vizsgálatban $(\mathrm{n}=38)$ oxaliplatinkezelés előtt és 48 órával a kezelés után keringő daganatsejteken (CTC) vizsgálták az ERCCl-ex- pressziót. Nyolc páciensnél találtak ERCCl-expressziót a kezelés előtt. Ezen páciensek közül három esetben fokozódott az ERCCl-expresszió a kezelés hatására, mely a betegség rapid progressziójával korrelált [12]. Egy másik vizsgálat alapján $(\mathrm{n}=65)$ demonstrálták, hogy az ERCCl-expressziónak statisztikailag jelentős prediktív szerepe van a túlélésre nézve [13]. Oxaliplatinrezisztenciához vezethet a serum deprivation response-related gene product that binds to c-kinase (SRBC) gén epigenetikus inaktivációja a foszfodiészterkötéssel kapcsolt citozin és guanin ( $\left.\mathrm{CpG}^{-}\right)$sziget hipermetilációja által. A folyamat során a dezoxiribonukleinsav (DNS)-javító breast cancer I (BRCAl) fehérje aktiválódik, így az oxaliplatin okozta DNS-keresztkötések kijavításra kerülnek [14]. Más, klinikailag releváns mechanizmusok is közrejátszhatnak az oxaliplatinrezisztencia kialakulásában, mint az ATP7Bfehérje és a hírvivő ribonukleinsav (mRNS) emelkedett expressziója, a GSTPl izoleucin (Ile)-105valin (Val) polimorfizmus (Ile/Ile genotípus; Ile-allél), ERCCl C118T polimorfizmus (citozin/guanin genotípus), XRCCl arginin (Arg)-399-glutamin (Gln) polimorfizmus (Arg/Arg genotípus; Gln/Gln genotípus), XPD lizin (Lys)-751-Gln polimorfizmus (Gln-allél; Lys/Gln genotípus; Lys-allél), a FoxMl magas mRNS-expressziója és a mikro-RNS (miR) -27b, -148a és -326 magas expressziója [15]. A topoizomeráz (TOPO)-1 specifikus célpontja az irinotekánnak. Az alacsony TOPOl-expresszió az irinotekánnal szembeni rezisztenciát jelzi [16]. Egy vizsgálat $(\mathrm{n}=49)$ alapján a TOPOl-expreszszió nem bizonyult az irinotekán prediktív markerének áttétes CRC-ben [17]. Egy másik vizsgálat szerint $(\mathrm{n}=98)$ [18] a TOPOl és a karboxilészteráz-2 (mely az irinotekán aktív metabolitját állítja elő hidrolízis útján) [19] magas expressziója hosszabb PFS-sel és OS-sel társult. A timidilát-szintáz (TS) amplifikációja az 5FU- [20] és a CAPE- [21] rezisztenciát jelzi. Mismatch repair (MMR-) deficientia esetén 5FU-rezisztencia áll fenn. Egy vizsgálat alapján CRC-ben $(\mathrm{n}=225)$ a páciensek 10,7\%-ában találtak dMMR-statust [22]. A topoizomeráz-2-alfa (TOP2A)-gén amplifikációja esetén az epirubicinkezelés jó hatásossága ismert, melyet oxaliplatinrefrakter áttétes CRC-ben is vizsgálnak (Eudract no. 2013-001648-79) [23]. A fenti prediktív markereket a 4. táblázat foglalja össze.

Abban az esetben, ha a megelőző kezelések során nem alakult ki kumulatív toxicitás, a korábban alkalmazott terápiák rechallenge kezelése már a 3. vonalban is megfelelőbbnek tünik, mint a regorafenib vagy a trifluridin/ tipiracil alkalmazása [24]. Az első vonalban adott irinotekán- vagy oxaliplatinalapú kombinációk rechallenge kezelésként történő alkalmazása a 3. vagy a 4. vonalban abban az esetben túnik jó választásnak, ha az első vonalbeli kezelés alatt a PFS $\geq 12$ hónap volt $(\mathrm{n}=39)$ [25]. Más szerzők már akkor is javasolják a fenti kombinációk rechallenge formában történő adását, ha a korábbi kezelés alatt a progresszió legalább hat hónap után következett be [24]. 
4. táblázat A CRC-ben alkalmazott kemoterápiás szerek érzékenységét/ rezisztenciáját előre jelző markerek

\begin{tabular}{llll}
\hline Kemoterápia & Marker & Érzékenység & Rezisztencia \\
\hline Oxaliplatin & ERCCl & Nincs expresszió & $\begin{array}{l}\text { Fokozott } \\
\text { expresszió }\end{array}$ \\
\hline Irinotekán & TOPO1 & Nincs amplifikáció & Amplifikáció \\
\hline 5-Fluorouracil & TS & Nincs amplifikáció & Amplifikáció \\
& MSI & Stabil & Instabil \\
\hline Kapecitabin & TS & Nincs amplifikáció & Amplifikáció \\
& MSI & Stabil & Instabil \\
\hline
\end{tabular}

CRC = vastag- és végbélrák; ERCCl = excision repair cross complementing group $1 ;$ MSI = mikroszatellitainstabilitás; TOPO = topoizomeráz; TS = timidilát-szintáz

Ismert, hogy az oxaliplatin rechallenge kezeléstől akkor várható jó hatás, ha a megelőző oxaliplatinkezelés után legalább hat hónap eltelt [26]. A kemoterápia vonatkozásában fontos, bár kis esetszámú $(\mathrm{n}=33)$ fázis II vizsgálatot közöltek 2015-ben. A vizsgálatba olyan betegeket vontak be, akik korábban kemoterápiában részesültek, beleértve az oxaliplatint és az irinotekánt is, és ezek mellett a terápiás választ vagy stabil betegséget követően progresszió alakult ki. Ezeknél a betegeknél az oxaliplatint újraindították. Fontos feltétel volt, hogy az oxaliplatin rechallenge előtt legalább 6 hónapnak el kellett telnie az utolsó oxaliplatinkezelést követően. A vizsgálat elsődleges végpontja a betegség-kontrollráta (DCR = disease control rate) volt 12 héttel a rechallenge-et követően. A DCR a komplett és a parciális remissziót, illetve a stabil betegséget elérő betegek számát jelentette. A DCR 39,4\% (95\% CI 21,8-57,0) volt, ezen belül az objektív válasz (komplett és parciális remisszió) 6,1\%. A rechallenge kemoterápia medián értéke 5 ciklus volt, a medián oxaliplatindózis $425 \mathrm{mg} / \mathrm{m}^{2}$. A medián PFS 98 nap, illetve a medián OS 300 nap volt. A $\geq$ grade III mellékhatások száma minimális volt (allergiás 3,1\%, perifériás szenzoros neuropathia 0\%), kezeléssel összefüggő haláleset nem fordult elő [27]. Azonban a kumuláció miatt kialakuló oxaliplatin immunindukált szindróma (OIIS) határt szab az oxaliplatinbázisú kemoterápia folytatásának és újraindításának. Egy elemzés alapján $(\mathrm{n}=61)$ az OIIS kialakulása átlagosan a 16. ciklus (a legkorábbi OIIS a 13. ciklus) után következett be, azonban rechallenge esetén már a 4 . ciklus után OIIS alakult ki [28]. Egy vizsgálat során $(\mathrm{n}=126)$ az OIIS az esetek 78,6\%-ában oxaliplatin rechallenge kezelés során alakult ki. Ezen páciensek közül azok (80,8\%), akik az úgynevezett rechallenge protokoll szerint kapták a további kezeléseket az OIIS megjelenése után, átlagosan három ciklust kaptak (tartomány: 1-29). A rechallenge protokollt három lépcsőben alkalmazták, és a korábbi lépcsőket a páciensek nagyobb hányada kapta meg. 1. lépcső (80\%): szteroid, hisztamin-1-receptor-blokkoló és/vagy hisztamin-2-receptor-blokkoló; 2. lépcső (18,75\%): szteroid eszkalációs dózisban (maximum 500 mg hidrokorti- zonekvivalens dózisig) és/vagy elnyújtott adagolású (2-6 óra) oxaliplatininfúzió; 3 . lépcső $(1,25 \%)$ : 2 . lépcső és adrenalin subcutan injekció. Az oxaliplatin rechallenge kezelést az esetek 56\%-ában progresszió és 21\%ában OIIS miatt kellett abbahagyni [29]. Amennyiben a páciensnél nem jelentkeznek OIIS-re utaló tünetek, úgy 6 ciklus oxaliplatintartalmú rechallenge kezelést követő 5FU/LV fenntartó terápia javasolható, mivel a relatív kockázat (RR), a PFS és az OS vonatkozásában ugyanolyan eredményt biztosít e séma alkalmazása, mint ha az oxaliplatin rechallenge kezelést a progresszióig vagy az elviselhetetlen toxicitás kialakulásáig folytatták volna [30]. Egy vizsgálat alapján $(\mathrm{n}=22)$ az adjuváns FOLFOX-kezelés után (medián 44,3 hónap) relaptálódó pácienseknél megismételt oxaliplatintartalmú kezeléssel a medián PFS 3,3 hónap (95\%-os CI: 1,4-5,1), míg az OS 10 hónap (95\%-os CI: 5,3-14,6) volt [31].

A kemoterápiás szerek iránti érzékenység fenntartható az intermittáló kezelési stratégiával, vagyis terápiás szünetek beiktatásával. Lényege az alkalmazott kezelés felfüggesztése a betegség azon állapotában, amikor még nem alakult ki a gyógyszer-rezisztencia. Az intermittáló kezelés akkor választandó, amikor nincs szükség arra, hogy jelentős daganatcsökkenés következzen be. Ezzel a kezelési stratégiával a kumulatív toxicitás mérséklésére és a jobb életminőség megtartására törekszik a kezelőorvos ahelyett, hogy az intenzív kezeléssel az OS meghosszabbítását tűzné ki célul. A kemoterápiamentes intervallum stratégiájának alkalmazása esetén pedig bizonyos hatóanyagok kihagyását követően úgynevezett fenntartó kezelésben részesül a páciens [32]. A fenntartó kezelésre vonatkozó részletes ESMO-ajánlások egyénre szabott alkalmazása és a terápiás terv megbeszélése elengedhetetlen részét kell, hogy képezze a páciensek ellátásának [1].

A biológiai terápiákat illetően az adatok azt igazolják, hogy a cetuximab [33] rechallenge ugyancsak megvalósítható. Egy vizsgálatban CET + FOLFIRI rechallenge esetén $(\mathrm{n}=39)$ a teljes válaszarány $58,6 \%$, míg a PFS 6,6 hónap volt, azonban a bőrmellékhatások is jelentősnek bizonyultak $(\mathrm{p}=0,01)$ [34]. Ám az anti-EGFR rechallenge kezelés terápiás sorba illesztéséről még nem állnak rendelkezésre klinikai vizsgálati adatok. A jövőben a döntés alapját valószínúleg a CTC-DNS-ből meghatározott mutációs mintázat fogja megszabni [24], mivel például a Kirsten rat sarcoma (K-ras) fehérjét kódoló gén (KRAS) másodlagos mutációja hozzájárulhat az antiEGFR-terápiával szemben szerzett rezisztenciához [35].

Egérmodelleken megfigyelték, hogy a vascularis endothelialis növekedési faktor (VEGF-) gátlók alkalmazásának felfüggesztését követő 7. napra a daganatos érhálózat teljes mértékben visszanőtt [36]. Ezen preklinikai adatok és a lezárult klinikai vizsgálatok alapján a terápiás szünetek nélküli fenntartó BEV-kezelés hatásossága bizonyítást nyert [32]. Az indukciós $\mathrm{BEV}+(\mathrm{CAPE}+$ oxaliplatin) CAPOX utáni fenntartó BEV + CAPE adása jelentősen javítja az OS-t (21,7 versus 17,9 hónap, 
5. táblázat $\mid$ A betegünknél alkalmazott kezelési szekvenciák az igénybe vett időtartam feltüntetésével

\begin{tabular}{|c|c|c|c|}
\hline Vonal & Séma & $\begin{array}{l}\text { Megadott } \\
\text { ciklusszám }\end{array}$ & $\begin{array}{l}\text { Idótartam } \\
\text { (hónap) }\end{array}$ \\
\hline 1. & $\mathrm{BEV}+\mathrm{FOLFOX}$ & 13 & 6,5 \\
\hline 1. & $\mathrm{BEV}+\mathrm{CAPE}$ & 2 & 1,5 \\
\hline 1. & $\mathrm{BEV}+5 \mathrm{FU} / \mathrm{LV}$ & 7 & 3,5 \\
\hline \multicolumn{3}{|c|}{ Várakozási ido" OEP-engedélyre } & 1 \\
\hline 1. & $\mathrm{BEV}+5 \mathrm{FU} / \mathrm{LV}$ & 5 & 2,5 \\
\hline 2. & CET + FOLFIRI & 28 & 14 \\
\hline \multicolumn{3}{|c|}{ Májsebészeti konziliumok, CT-k miatti várakozás } & 2 \\
\hline 3. & TACE & 2 & 2 \\
\hline \multicolumn{3}{|c|}{ Várakozás OEP-EMK-ra } & 2 \\
\hline 4. & Trifluridin/tipiracil & 4 & 4 \\
\hline \multicolumn{3}{|c|}{ Várakozási idó NEAK-engedélyre } & 1 \\
\hline 5 . & $\mathrm{BEV}+\mathrm{FOLFIRI}$ & 13 & 6,5 \\
\hline \multicolumn{3}{|c|}{$\begin{array}{l}\text { A kezelések egyéb okból történö halasztásának összes } \\
\text { idootartama }\end{array}$} & $\begin{array}{l}4,82 \\
(1,27 \text { hó/év })\end{array}$ \\
\hline \multicolumn{3}{|c|}{ A kezelés megkezdésétöl a halálig terjedö idötartam } & 51,32 \\
\hline
\end{tabular}

$5 \mathrm{FU}=5$-fluorouracil; $\mathrm{BEV}=$ bevacizumab; $\mathrm{CAPE}=$ kapecitalin ; CET = cetuximab; EMK = egyedi méltányossági kérelem; FOLFIRI = 5-fluorouracil + leukovorin (kalcium-folinát) + irinotekán; FOLFOX = 5-fluorouracil + leukovorin (kalcium-folinát) + oxaliplatin; LV = leukovonin (kalcium-folinát); NEAK = Nemzeti Egészségbiztosítási Alapkezelö; OEP = Országos Egészségbiztosítási Pénztár; TACE = transarterialis chemoembolisatio

$\mathrm{p}=0,02)$ [37]. Továbbá a progresszión túli kezelés hatásossága is ismert [32]. Tekintettel arra, hogy a BEV fenntartó kezelésekkel a páciensek döntő többsége hatékonyan kezelhető a 2. vonalban, a 3. és 4 . vonalban alkalmazott BEV rechallenge kezelés hatásosságáról kevés adat áll rendelkezésre.

Egy 63 éves páciensnél végbéldaganat okozta irreszekábilis májáttét miatt az ötödik vonalban újraindították az első vonalban hatékony - megközelítőleg 30 hónap stabil betegséget eredményező - BEV + FOLFIRI kezelést. Az újraindított (rechallenge) kezelést 6 hónapon keresztül tudták folytatni, mialatt a páciens jó általános állapotnak örvendett [38]. A BEV rechallenge kezelés jól tolerálható, azonban egy esetben leírták, hogy ennek során dysphonia alakult ki, melyet a légcső és a garat nyálkahártya-kapillárisainak megszakadása okozott [39].

\section{Következtetés}

Esetünkben a 65 éves páciensnél az ötödik vonalban újraindított $\mathrm{BEV}$ - és a második vonalban hatékony FOLFIRI-kezelés kombinációja 6,5 hónappal hosszabbította meg az OS-t. A beteg 4 év és 3 hónap időtartamban (5. táblázat) részesült - az engedélyek beszerzéséhez szükséges időintervallumokat leszámítva - folyamatos kezelésben, jó életminőség megtartása mellett. A BEVkezelésre azért esett a választás, mert a két biológiai szer közül ennek az alkalmazása óta telt el a legtöbb idő. Ebból kifolyólag valószínúsíthetően a daganatsejtek nagyobb hányada mutatott érzékenységet erre a kezelésre, mint ha az anti-EGFR-terápiát alkalmaztuk volna. Az irinotekánkezelést biztonságosabbnak ítéltük meg az oxaliplatinterápiával szemben, mivel az utóbbinál számolni lehetett a kumuláció miatti OIIS kialakulásával. $\mathrm{Az}$ alkalmazott kezelést jól viselte a páciens, és csak az utolsó kezeléstől számított szúk két héten belül jelentkezett a rohamos leépülés.

Anyagi támogatás: A közlemény megírása anyagi támogatásban nem részesült.

Szerzői munkamegosztás: D. D.: Irodalomkutatás, a közlemény szövegének megszerkesztése és gondozása. T. A.: A korábbi kéziratváltozatok áttekintése és kiegészítése. A cikk végleges változatát mindkét szerző elolvasta és jóváhagyta.

Érdekeltségek: A szerzőknek nincsenek érdekeltségeik.

\section{Irodalom}

[1] Van Cutsem E, Cervantes A, Adam R, et al. ESMO consensus guidelines for the management of patients with metastatic colorectal cancer. Ann Oncol. 2016; 27: 1386-1422.

[2] Cervantes A, Arnold D, Peeters M, et al. Redefining later-line therapy in metastatic colorectal cancer. EMJ 2017; 2: 31-37.

[3] Bano N, Najam R, Quazi F, et al. Clinical features of oxaliplatin induced hypersensitivity reactions and therapeutic approaches. Asian Pac J Cancer Prev. 2016; 17: 1637-1641.

[4] Lenz HJ. Management and preparedness for infusion and hypersensitivity reactions. Oncologist 2007; 12: 601-609.

[5] Goldberg RM, Rothenberg ML, Van Cutsem E, et al. The continuum of care: a paradigm for the management of metastatic colorectal cancer. Oncologist 2007; 12: 38-50.

[6] de Gramont A, Buyse M, Abrahantes JC, et al. Reintroduction of oxaliplatin is associated with improved survival in advanced colorectal cancer. J Clin Oncol. 2007; 25: 3224-3229.

[7] Yeoh C, Chau I, Cunningham D, et al. Impact of 5-fluorouracil rechallenge on subsequent response and survival in advanced colorectal cancer: pooled analysis from three consecutive randomized controlled trials. Clin Colorectal Cancer 2003; 3: 102107.

[8] Schmoll HJ, Van Cutsem E, Stein A, et al. ESMO consensus guidelines for management of patients with colon and rectal cancer. A personalized approach to clinical decision making. Ann Oncol. 2012; 23: 2479-2516.

[9] Baldus SE, Schaefer KL, Engers E, et al. Prevalence and heterogeneity of KRAS, BRAF and PIK3CA mutations in primary colorectal adenocarcinomas and their corresponding metastases. Clin Cancer Res. 2010; 16: 790-799.

[10] Sagaert X, Vanstapel A, Verbeek S. Tumor heterogeneity in colorectal cancer: what do we know so far? Pathobiology 2018; 85: 72-84.

[11] Ma SC, Zhao Y, Zhang T, et al. Association between the ERCCl rs11615 polymorphism and clinical outcomes of oxaliplatinbased chemotherapies in gastrointestinal cancer: a meta-analysis. Onco Targets Ther. 2015; 8: 641-648.

[12] Di Salvatore M, Orlandi A, Paolillo C, et al. ERCCl biomarker in colorectal cancer: to induce or not to induce? This is the matter! Oncomedicine 2016; 1: 25-27. 
[13] Serban A, Hajdu KA, Banciu TI, al. The choice of irinotecan or oxaliplatin-based chemotherapy in metastatic colo-rectal cancer as first line treatment: Impact on survival (ERCCl and TOPOl adjusted analysis). Ann Oncol. 2017; 28 (Suppl 3): iiil3-iiil36.

[14] Moutinho C, Martinez-Cardús A, Santos C, et al. Epigenetic inactivation of the BRCAl interactor SRBC and resistance to oxaliplatin in colorectal cancer. Natl Cancer Inst. 2014; 106: dit322.

[15] Martinez-Balibrea E, Martínez-Cardús A, Ginés A, et al. Tumorrelated molecular mechanisms of oxaliplatin resistance. Mol Cancer Ther. 2015; 14: 1767-1776.

[16] Sugimoto Y, Tsukahara S, Oh-hara T, et al. Decreased expression of DNA topoisomerase I in camptothecin-resistant tumor cell lines as determined by a monoclonal antibody. Cancer Res. 1990; 50: 6925-6930.

[17] Cunningham JM, Prins P, Conkright B, et al. Molecular profiling of TOPOl: a way to evaluate irinotecan treatment in colorectal cancer? J Clin Oncol. 2016; 34(Suppl): 546.

[18] Shaojun C, Li H, Haixin H, et al. Expression of topoisomerase 1 and carboxylesterase 2 correlates with irinotecan treatment response in metastatic colorectal cancer. Cancer Biol Ther. 2018; 19: 153-159.

[19] Paolicchi E, Vivaldi C, De Gregorio V, et al. Topoisomerase 1 promoter variants and benefit from irinotecan in metastatic colorectal cancer patients. Oncology 2016; 91: 283-288.

[20] Peters GJ, Backus HH, Freemantle S, et al. Induction of thymidylate synthase as a 5 -fluorouracil resistance mechanism. Biochim Biophys Acta 2002; 1587: 194-205.

[21] Park DJ, Stoehlmacher J, Zhang W, et al. Thymidylate synthase gene polymorphism predicts response to capecitabine in advanced colorectal cancer. Int J Colorectal Dis. 2002; 17: 46-49.

[22] Leicher LW, Lammertink MH, Offerman SR, et al. Consequences of testing for mismatch repair deficiency of colorectal cancer in clinical practice. Scand J Gastroenterol. 2017; 53: 632-636.

[23] Tarpgaard LS, Qvortrup C, Nygård SB, et al. A phase II study of epirubicin in oxaliplatin-resistant patients with metastatic colorectal cancer and TOP2A gene amplification. BMC Cancer 2016; 16: 91 .

[24] Vogel A, Hofheinz RD, Kubicka S, et al. Treatment decisions in metastatic colorectal cancer - beyond first and second line combination therapies. Cancer Treat Rev. 2017; 59: 54-60.

[25] Ozaslan E, Duran AO, Bozkurt O, et al. Analyses of multiple factors for determination of "selected patients" who should receive rechallenge treatment in metastatic colorectal cancer: a retrospective study from Turkey. Asian Pac J Cancer Prev. 2015; 16: 2833-2838.

[26] Chibaudel B, Tournigand C, Bonnetain F, et al. Platinum-sensitivity in metastatic colorectal cancer: towards a definition. Eur J Cancer 2013; 49: 3813-3820.
[27] Suenaga M, Mizunuma N, Matsusaka S, et al. Phase II study of reintroduction of oxaliplatin for advanced colorectal cancer in patients previously treated with oxaliplatin and irinotecan: REOPEN study. Drug Des Devel Ther. 2015; 9: 3099-3108.

[28] Bencardino K, Mauri G, Amatu A, et al. Oxaliplatin immuneinduced syndrome occurs with cumulative administration and rechallenge: single institution series and systematic review study. Clin Colorectal Cancer 2016; 15: 213-221.

[29] Yanai T, Iwasa S, Hashimoto H, et al. Successful rechallenge for oxaliplatin hypersensitivity reactions in patients with metastatic colorectal cancer. Anticancer Res. 2012; 32: 5521-5526.

[30] Tournigand C, Cervantes A, Figer A, et al. OPTIMOXl: a randomized study of FOLFOX4 or FOLFOX7 with oxaliplatin in a stop-and-go fashion in advanced colorectal cancer - a GERCOR study. J Clin Oncol. 2006; 24: 394-400.

[31] Peixoto RD, Kumar A, Lim HJ, et al. Palliative oxaliplatin-based chemotherapy after exposure to oxaliplatin in the adjuvant setting for colon cancer. J Gastrointest Oncol. 2015; 6: 487-491.

[32] Tonini G, Imperatori M, Vincenzi B, et al. Rechallenge therapy and treatment holiday: different strategies in management of metastatic colorectal cancer. J Exp Clin Cancer Res. 2013; 32: 92.

[33] Ma J, Yang QL, Ling Y. Rechallenge and maintenance therapy using cetuximab and chemotherapy administered to a patient with metastatic colorectal cancer. BMC Cancer 2017; 17: 132.

[34] Santini D, Vincenzi B, Addeo R, et al. Cetuximab rechallenge in metastatic colorectal cancer patients: how to come away from acquired resistance? Ann Oncol. 2012; 23: 2313-2318.

[35] Misale S, Yaeger R, Hobor S, et al. Emergence of KRAS mutations and acquired resistance to anti-EGFR therapy in colorectal cancer. Nature 2012; 486: 532-536.

[36] Mancuso MR, Davis R, Norberg SM, et al. Rapid vascular regrowth in tumors after reversal of VEGF inhibition. J Clin Invest. 2006; 116: 2610-2621

[37] Simkens LH, van Tinteren H, May A, et al. Maintenance treatment with capecitabine and bevacizumab in metastatic colorectal cancer (CAIRO3): a phase 3 randomised controlled trial of the Dutch Colorectal Cancer Group. Lancet 2015; 385: 18431852.

[38] Kamiya M, Yoneyama K, Doi Y, et al. A case of rectal cancer with unresectable liver metastasis responding to rechallenge with FOLFIRI. Gan To Kagaku Ryoho 2016; 43: 2277-2279. [Article in Japanese]

[39] Carter CA, Caroen SZ, Oronsky AL, et al. Dysphonia after bevacizumab rechallenge: a case report. Case Rep Oncol. 2015; 8: $423-425$.

(Deme Dániel dr., Salgótarján, Füleki út 54-56., 3100 e-mail: danieldeme_md@ymail.com)

\section{"Accidere ex una scintilla incendia passim." (Lucretius) (Egyetlen szikrából több helyen tüzvész keletkezik.)}

A cikk a Creative Commons Attribution-NonCommercial 4.0 International License (https://creativecommons.org/licenses/by-nc/4.0) feltételei szerint publikált Open Access közlemény, melynek szellemében a cikk nem kereskedelmi célból bármilyen médiumban szabadon felhasználható, megosztható és újraközölhető, feltéve, hogy az eredeti szerző és a közlés helye, illetve a CC License linkje és az esetlegesen végrehajtott módosítások feltüntetésre kerülnek. 